\title{
Ghazali's Sufism and Its Influence in Indonesia
}

\author{
A. Ilyas Ismail \\ UIN Syarif Hidayatullah, Jakarta \\ email: ilyassendany@gmail.com
}

\section{Badrah Uyuni}

As-Syafi'iyyah Islamic University, Jakarta

email: badrahuyuni.fai@uia.ac.id

\begin{abstract}
This study aims to describe Ghazali's sufism and its influences in SoutheastAsia, mainly in Indonesia. Al-Ghazali is a renowned Muslim intellectual who has a special place at every Moslem's heart, especially in Indonesia. He possesses encyclopedic expertise within various disciplines, ranging from figh and ulusulfigh, al-kalam, logic, philosophy, and sufism. Despite his vast expertise, his practices are more well-known in sufism than in Islamic law, theology, and philosophy due to his long journey, exquisite experience, and groundbreaking thinking within the discipline of Sufism. Ghazali developed a new method of thinking within Islamic epistemology, widely known as Irfani epistemology. One of Ghazali's biggest achievements is that Ghazali is considered successful in integrating between Sufism and the fiqh (sharia) Ghazali demonstrated his intellectual brilliance of integrating both branches of Islamic thinking (between sharia and the essence of Islam). Ghazali's notable influence and position within the discipline of sufism made him granted the title of “Hujjat al-Islam".Ghazali'sSufism spreads and influences the development of Sunni Islam not only in the Arabian peninsula but also in Indonesia and Southeast Asia.
\end{abstract}

\section{Keywords:}

Ghazali, Sufism, Indonesia, Pesantren, Tareeqa 


\section{Introduction}

Imam Ghazali is a renowned Muslim intellectual who has a special place at every Moslem's heart. He possesses encyclopedic expertise within various disciplines, ranging from fiqh and ulusulfiqh, al-kalam, logic, philosophy, and Sufism. Despite his vast expertise, his practices are more well-known in Sufism than in Islamic law, theology, and philosophy due to his long journey, exquisite experience, and groundbreaking thinking within the discipline of Sufism.

As Ghazali himself spoke within his autobiography, al-Munqidz min al-Dhalal (Deliverance from Error) (Qardhawi, n.d.: 6-12), Ghazali only believes truth as obtained from intuitive method (kasyf), i.e. self-purification method that involves prayers to Allah to be granted enlightened knowledge of truth directly to the chosen servant He wishes (Nuryuqdzif Allah fiQalb $` A b d$ ). As mentioned in his autobiography, Ghazali preferred not to accept truth obtained only from the mind and five basic senses, as he perceived both mind and the five senses could be deceiving and misleading human beings from reaching the truest truth in essence (essence, Arabic: haqiqab). Ghazali spoke that truth is explorable truth from 4 (four) gates, i.e. logic (al-Kalam), mysticism (al-Batbiniyyah), philosophy (al-Falsafah), and Sufism (at-Tasawnf). Sufism was chosen to be Ghazali's way of seeking for the truth, as Ghazali perceives that Sufism encourages soul purification and intense communication with Allah the Most glorified (Al-Taftazani 1979: 159).

Ghazali developed a new method of thinking within Islamic epistemology, widely known as Irfani epistemology (Ismail 2013: 135). His contribution towards the discipline of Sufism is observable within intellectual battles of the Islamic school of thought against different sides, two of which are heretic spiritual groups popularly known as al-Bathiniyyah and liberal-Islamic thinkers and philosophers whose perspective towards Islam is influenced mainly from Greek philosophy. Ghazali's criticism on

DINIKA, Volume 4, Number I, January - April 2019 
heretic spiritual practitioners in Persia is written within his book, Fadhaikh al-Bathiniyyah, which unravels the heresy of their teachings. Within the introductory section of his book, he argues that the purpose of revealing the wrong teachings is not meant to perpetuate the heresy. It is only to save mankind from apostasy, for one who cannot understand atrocity can fall into it. Then he presented his criticism towards liberal Islam scholars/ philosophers within his two prominent books, i.e.: Maqashid al-Falasifah and Tahafut al-Falasifah. Ghazali in this book challenged the ambiguity of the philosophers' perspective on Islam in various aspects, mainly related to three core issues, i.e. the state of nature existence, state of God's omnipotence, and debates on the spirituality state of judgment in afterlife. In facing challenges from both streams, Ghazali took the middle ground and developedwasathiyyah, i.e., balanced and integrative way of thinking that synchronizes different entities, i.e., between logic and revelation, and between sufism and sharia.

Moreover, Ghazali actually criticized almost every logo in Islam, ranging from Islamic theology, Islamic law (figh), and Islamic philosophy. Within Islamic theology, Ghazali referred to his mentor, al-Juwaini (alImam al-Haramayn) that challenges Mu'tazilah school of thought by supporting Ahlus-sunnah Wal-jama'ah scholarship. He supported the criticism towards the shallowness of Islamic fiqh due to its legal-formalistic state and its contrasting values against essence of Islamic values. Ghazali also highlighted the values of Sufism and spirituality that contradicts the basic ontological foundation of the Quran and Sunnah. Moreover, he denounced the principles of philosophy for its failure to bring mankind to enlightenment to achieve the ultimate truth. On the other hand, Ghazali also received harsh criticisms from various sides, e.g. Ibn Taimiyah and from the Salafi group. This, according to Qardhawi, is related to Ghazali's stance and attitude towards various branches of Islamic thinking that spreads at the time (Qardhawi, n.d.: 5). 
One of Ghazali's biggest achievements is that Ghazali is considered successful in integrating between Sufism and the figh (sharia) Ghazali demonstrated his intellectual brilliance of integrating both branches of Islamic thinking (between sharia and the essence of Islam) within his most prominent creation, Ibya Ulum al-Din. The book received big praise and was widely welcomed within Muslim communities. Consequently, sufism became widely accepted and practiced within Islamic laws and the community by virtue of Ghazali's thinking. This milestone remarks Ghazali's key position within the discipline of Sufism. Taj al-Din alSubukiin his book Thabaqat al-Syafi iyah al-Kubraonce stated, "if no other kitab [holy book] had existed on Earth, then Ibya' 'Ulum al-Din would have been enough for mankind as guidance. (Hamid, n.d.) also receives praise from one of the Indonesian most-respected Islamic thinkers, Nurcholish Madjid, who described the book as a comfortable chamber full of soothing breeze that makes whoever who enters the room will never want to come out anymore (Madjid 1984: 28-35).

Ghazali's notable influence and position within the discipline of Sufism made him granted the title of "Hujjat al-Islam".Ghazali'sSufism spreads and influences the development of Sunni Islam not only in the Arabian peninsula but also in Indonesia and Southeast Asia. This study aims to describe Ghazali's Sufism and its influences in Southeast Asia, mainly in Indonesia.

\section{Brief Description of Ghazali's Biography}

Al-Ghazali was born with the name Abu Hamid Muhammad bin Muhammad al-Ghazali. He was born in Thus, one of the cities within Khorasan (Persia) during the middle of the fifth century of Hijri/Islamic year $(450 \mathrm{H} / 1058 \mathrm{AD})$, within the city also were born some of the notable Islamic figures, e.g., a well-known Islamic cleric and poet al-Firdawsi, and two famous Sufism scholars, Abu Yazid al-Bustami (188-261 H/804-875

DINIKA, Volume 4, Number I, January - April 2019 
AD) and Husaynibn Mansur al-Hallaj (244-309 H/858-921 AD) (AlSubuki 1992: 191).

In several references, Ghazali's father was said to be a devout Muslim with strong Islamic figh foundation, however, the validity of the references is doubted. Another version of Ghazali'sfather's story told that Ghazali's father was not a Muslim cleric, but he was only an ordinary yarn spinner. The name Ghazali, by this version, is the attribution of his father's job. Ghazali's father may not be a cleric, but he was well-known for his love and devotion to Islam.His father was described as an ascetic person (wara') that practices severe self-discipline, abstention from all forms of indulgence, and does not accept things resulted not from his own efforts. Ghazali's father was said to regularly visit Islamic scholars to extend his knowledge of Islam and to ask for religious advice. He passed away when Ghazali and his brother, Ahmad, were still toddlers. Moments before his death, his father sent young Ghazali to several Islamic clerics to study Islam.(Ghazali 2013: 65-68)

During his early ages, Ghazali studied in his hometown. He spent his early years being a disciple of Ahwad bin Muhammad ar-Radzikani. Ghazali then went to Jurjani (400-471 or 474 H/1078 AD) to study withAbiNashr al-Ismaili (Receiving such amount of knowledge, Ghazali continued studying Islam inNeisabur, a town known as the center for Islamic studies at the time. There he went to al-Juwaini entitled as alHaramayn to learn more about Islamic principles. The story told that alJuwaini was impressed by Ghazali's excellence, by which he encouraged Ghazali to lead discussions and scientific meetings. Juwaini himself was a professor and the Rector of Nizamiyya Academy in Baghdad.

After the death of Juwaini, Ghazali was mandated to be the Rector of the Nizhamiyah Academy, occupying the position left by his mentor. During this period, Ghazali began to contemplate and spark debates and denouncements against Islamic spiritualists (Bathiniyya) and Islamic 
philosophy scholars. His intellectual excellence and his position as the Rector of Nizamiyya Academy contributed to the spread of his fame and popularity within Islam communities. Nonetheless, during the peak of his career, Ghazali was described to suffer from 'mental disorder', some kind ofskepticism or doubts (al-syakk) of principles of the truth of the mind and senses, as Ghazali stated himself within his autobiography, al-Munqidz. min al-Dhalal (Hamid, n.d.: 12).

Having this doubtful mind of truth, Ghazali left his position as the Rector of Nizamiyya Academy. He then spent years wandering around Muslim regions, e.g., spending two years in Damascus, visiting Palestine and observing the Hajj pilgrimage to Mecca. A story narrated during these periods, Ghazali began working on his magnum opus, the renowned book Ihya' Ulum al-Din. His intellectual anxiety slowly disappeared when Ghazali chose to spend his final years living far from earthly indulgence as a sufis. He chose to continue life relying on sufism values as his final phase of the intellectual and spiritual journey. Ghazali spent his final days and passed away in his hometown, Thus, on 14th of JumadilAkhir 505 Hijri (December 19, 1111AD)

\section{Ghazali's Sufism}

Prior to proceeding with the discussion of Ghazali'ssufism, it is essential to know that Ghazali is not among the first scholars within the discipline of sufism. Long before Ghazali, especially during the 3rd century of Hijri year, there were some notable figures within sufism. Some of the figures are Haris al-Muhasibi (d. 243 H/857 AD) who wrote alRi ayah li Huquq Allah, Abu Sa id al-Kharraz (d. 227 Hijri) with his works al-Thariqila Allah and al-Shidq, Dzunnun al-Mishri (d. 245 H/862 AD) with his book al-Mujarrabat, and Junaid al Baghdadi (d. 298 H/910 AD), with his bookRisalah al-Junaid, and Al-Qushairy (d. 465 H/1072 AD), with his book Risalah Al-Qusyairiyyah (Ghazali 2013: 70-75)

DINIKA, Volume 4, Number I, January - April 2019 
Within this period (3rd century of Hijri year), researchers argue that the principles of sufism emphasized on self-purification, religious rituals, dzikr (prayers), and full devotion to Allah (al-Thuruqila Allab). During this period also the principles of unification and fusion between man and God were introduced in the discipline of sufism, as observed within principles of al-Ittihad from Abu Yazid al-Busthami and bululbelief from Abu Mansur al-Hallaj. Ittihad etymologically means to unite between man and God. The term 'unity' however is not interpreted theoretically, but as a feeling of self-existence removal and awareness because of one's full devotion and love to Allah. The disappearance of self-awareness (in Sufism it is called fana' al-nafs) is replaced by full awareness of God; by which in this phase, one can no longer be aware and actualize him/herself, the only awareness left is for the existence of God. The 'unification' takes place within this phase. One the other hand, the concept of bululfrom Hallaj is of unification between man and God that slightly differs from Ittibadby Yazid. Entering the 5th and 6th centuries Hijri, this orientation then became more philosophical with the influences of the teachings of Neo-Platonism. In this case, the semi-philosophical orientation becomes entirely philosophical, so-called tasamuffalsafy. This flow is a school of Sufism that combines mystical vision and rational vision. This Sufism uses deep philosophical terminology.

Disclosure that comes from various kinds of philosophical teachings. Suhrawardi $(\mathrm{d} .638 \mathrm{H})$ with the theory of ishraqiyyah (illumination) and Ibn 'Arabī (d. $638 \mathrm{H})$ with the theory of wahdah al-wujüd (unitary existence) is the representative of this variant.

Imam Ghazali, on the other hand, stood with principles of Sufism that emphasize on the importance of prayers, religious rituals, soul and moral purification, love (mahabbah), and devotion (ma'rifah) to Allah. And also harmonize between irfanī and bayanī. Ghazali clearly denounced and defamed the concepts of unification between man and God, i.e.,ittihadby 
Abu Yazid and buluby al-Hallaj. In Ghazali's version of Sufism, the highest spiritual position the mankind can reach is mahabbah and ma'rifah. The book of Ibya' 'Ulum al-Din describes and discusses four core issues. The book provides complete description and elaboration of prayers (Ibadat), human interaction and culture (muamala), destructing behaviors (al-mublikat), and behaviors capable to bring mankind to salvation (al-munjiyat) respectively. The latter chapter discusses the phases of devoting to God (maqamat). (Ibrahim 2002: 453).

Ghazali'sSufism, as observable within his magnum opus Ibya' Ulum al-Din, relies on values of self-purification, the nobility of character, and intimacy to Allah (May He be glorified and exalted) by doctrines of mababbaband ma'rifah. Ghazali'sSufism denies the maqam of unification between man and God. Ghazali postulated that the doctrine of maqamah as phases of devotion to God should rely only on the main references of Islam, the Quran andSunna. In consequence, it is by no surprise that Ghazali'sSufismis widely identified as a Sunni version of Sufism, i.e., a variety of Sufism with an intellectual foundation based in the Quran and Sunnah. Ghazali'sSufismis also mentioned as Khuluqi-AmaliSufism (ortodox sufism), i.e., concepts of Sufism that focus on the moral quality and religious rituals capable of bringingmankind closer and more intimate to God based only on guidances from Allah and Rasulullah (the prophet) (Ghazali 2013: 76-78).

It is essential to point out that on the one hand, Ghazali openly expressed harsh criticism towards Sufism, mainly its elements of spirituality that derive from remote sources and not referable to the Quran and Sunnah. His denouncement of spirituality in Sufismis written in his work Fadhaikh al-Bathiniyyah (Hamid, n.d.), which literally means condemnation against the spiritualists. On the other hand, Ghazali also condemned the figh scholars whose interpretation of Islam is viewed to be rigid by the legal-formalistic approach and without further influences from spiritual

DINIKA, Volume 4, Number I, January - April 2019 
aspects which Ghazali valued to be the fundamental essence of Islam. The criticism was pointed out in Ibya' 'Ulum al-Din. Within the chapter that discusses Rub al-'Tbadat, Ghazali did not only mention the concepts and prerequisites of prayers as scriptures of fiqh in general, but it also elaborates the secrets beyond prayers. e.g.,asrar al-shalah, asrar al-shaum, and asrar al-hajj.

Thanks to al-Ghazali's hard work the development of Sunnitasawuf has become increasingly extraordinary. Departing from its satisfying understanding of the study of figh, ushulfigh and the science of kalam and its dissatisfaction with the method of truth seeking offered by philosophy, the concept of general Islamic Sufism and the sunnytasawuf in particular became very popular among the public. The concept of Sufism, in alGhazal's perspective, is the concept of Sufism which combines precisely between figh as a representative of exoteric aspects with ethics and aesthetics as an embodiment of the esoteric dimension.

This is to say that Ghazali contributed to three issues of Sufism. Firstly, Ghazali fundamentally brought back the discipline of Sufism from remote spiritual elements that did not refer to Islamic teachings, by which Sufism finally complies with Islamic law. Secondly, Ghazali synthesized moderation and balance between formerly contradicting values of figh (sharia) and Sufism (essence of Islamic spirituality) Thirdly, as the continuation from the former contributions, Ghazali was successful to strengthen the position of Sufism as teachings of Islamic inner spiritual aspect, in which it is widely accepted among the Muslim communities. Ghazali's concepts and influence spread widely within Sunni Muslim communities in the Middle East and across countries, including in Indonesia.

Ghazali's works and concepts also spread to the West. FazlurRahman (d. 1988 AD) asserts that Ghazali's influence is beyond predictable. He points out that Ghazali is capable to both reconstruct the foundation 
of Orthodox Islam by involving Sufism within its integral part; he also contributed towards innovations of Sufism and re-fundamentalized principles of Sufism from remote concepts that do not comply with Islam. It is by Ghazali's virtue that Sufism is finally accepted by Muslims through consensus (Rahman 2000: 28-38). His fame and popularity did not only result in praises and acknowledgments, but also criticisms and condemnations of his concepts.

Ghazali's thinking acquired many sides that support and praise his works. His book IhyaUlum al-Din is considered to be the best Islamic reference written by any Islamic scholars on Earth. Due to his harsh criticism towards spiritualists and philosophers, Ghazali also received denouncements and condemnations from those groups. One of the notable criticisms came from IbnTaimiyah (661-728 H/1963-1328 AD), who declares that Ihya' Ulum al-Din is full of errors, bid'ah, kburafat, fake badiths, and plagiarizing the works of previous Sufism scholars such as Abu Thalib al-Makki (d. 386 H/996 AD) and Haris al-Muhasibi (781-851 H). Other criticisms towards Ihya' 'Ulum al-Din were expressed by Yusuf Musa within his book, Falsafah al-Akblaq, in which he argues that Ghazali claimed works of Al-Raghib al-Isfahan as his own work. Meanwhile, Muhammad Zahid al-Kautsari mentions that Ghazali copied principles by Haris al-Muhasibi in the book al-Ri'ayahand Risalah al-Mustarsyidinwithout properly quoting the reference (Qardhawi, n.d.: 166).

Whether it is visible or not, the controversies of Ghazali's principles can only strengthen his fame and position. As one of the most prominent Islamic clerics in the world, Sheikh Yusuf al-Qardhawi (b. 1926 AD) brilliantly provided a detailed elaboration of contradicting perspectives of Ghazali's supporters and critics in his book, Al-Ghazali: BaynaMadibiwaNaqidzibi.

Based on the composition of the Ihya ' $m$ Ulum al-Din, the main thoughts of al-Ghazali concerning the relationship of the Sharia and the 
essence or tasawuf are reflected, namely before learning and practicing Sufism, one must first explore the knowledge of sharia and aqidah In addition, he also must consequently carry out the Sharia diligently and perfectly. In Ihya "Ulum al-Din explained the levels in the sharia, such as how to perform prayers, fasting and so on. It also distinguishes the level of prayer, between lay people, khawwash, and more specifically. Likewise fasting and so on. After carrying out the Sharia in an orderly and understanding manner, only then will it begin to study the tareeqa, which is about self-introspection, lust control, and finally succeed in achieving kasyf knowledge and understanding of ma'rifah.

\section{The Influence of Ghazali's Sufism in Indonesia}

Some studies noted that Islam in Indonesia during its early phase was influenced by three styles, i.e., Indian Islam, Persian Islam, and Arabic Islam. Indian Islam with Sufism (spiritualist) came to Indonesia through the merchants and wanderers from Gujarat, India. Persian Islam with Shi'a stream arrived in Indonesia by virtue of religious preachers from Persia (current Iran). On the one hand, the Arabic Islam with fundamentalism (Salafi) was spread by clerics from the Arabian peninsula. The fundamentalism of Islam contributed in the Paderi conflict, in which local clerics in Paderi, West Sumatra, condemned traditionalist beliefs as bid'ah and heretic. The researchers acknowledge, that the early Islamic preacher was brought by Sufism experts (A.Hasjmi: 46). That is, tasawuf indeed played an important role in the Islamization of the inhabitants of the archipelago. Sufism that develops in Indonesia involves two streams. The first stream is the earlier falsafiSufism that emphasizes on concepts of unification as preached by HamzahFansuri (d. 1590 AD) and SyamsuddinSumatrani $(1040 \mathrm{H} / 1630$ AD).The latter stream is KhuluqiAmaliSufism, or widely known as Sunni Sufism as criticism and correction towards the former stream. The Sunni Sufismwas brought by Sufism 
scholars, e.g.Nuruddin al-Raniri (d. 1958 AD), AbdurRauf al-Sinkili (d. 1105 H/1615 AD), AbdusShomad al-Palimbani (1116-1203 H/1704-1789 AD), the nine Walis (WaliSongo), Sheikh Yusuf al-Makasari (d. 1699 AD), and other figures. The figures studied Ghazali's concepts of Sufism from clerics in Arab, e.g., Imam al-Qusyairi (d. 1074 AD) and al-Kurani (d. 1145 $\mathrm{H}$ ), or Indonesian clerics that resided in the Arab peninsula (Huda 2008: 3).

Naturally when al-Ghazali, both because of his influence as a trusted ahl al-Sunnah, a brilliant Sufism thinker and also his great work (IbyaUlum al-Din), Sufism finally gained a place in the hearts of ahl al-Sharia and was accepted as part from the Islamic religious system that Muslims are very proud of generally. Even Sufism spread and populated all corners of the Islamic world, especially during the decline of Islamic thought for centuries, from the 13th century to the present. Sufism, everywhere is part of Islamic teachings which are the easiest and quickest to adapt to the traditions and even mysticism of the local community.

Ghazali has outlined the moderate concept of Sufism which can be accepted among the jurists, Ibn 'Arabi (560-638 H/1164-1240 AD), whose work greatly influences the teachings of almost all Sufis, and the founders of the tareeqa such asAbd. al-Qadir al-Jaylani (470-561 H/10771-165 AD.) whose teachings became the basis of the Qadiriyah order, Abu al-Najib alSuhrawardi (490-563 H/1096-1167 AD), Najmudddin al- Kubra (d. 618 $\mathrm{H} / 1221 \mathrm{AD}$ ) whose teachings greatly influenced the Naqshabandiyyah order, Abu al-Hasan al-Syadzali (560-638/1196-1258 AD) Sufi from Africa and founder of the Syadziliyyah order, Bahauddin al -Bukhari alNaqshabandi $(717-781 \mathrm{H})$.

There is no denying that the works of Ghazali were among the works that attracted the attention of European scholars too. Ghazali's popularity did not only take place in the world of Muslims, but also to non-Muslims. Ghazali's thinking for example incarnated in the works of 
Jewish philosophers named Musa ibn Maymun (Moses the Maimonedes) (1135-1204 AD). Interestingly, Maimonedes wrote a book in Arabic with the same name as a book by Imam al-Ghazali, namely al-Munqidz min al-Dhalal. Not only among Jews, had Ghazali's thinking also influenced medieval Christian thinkers such as Bonaventure (1221-1274 AD). In fact, the mysticism of Imam Ghazali influenced Catholic Christian mysticism of the Order of Franciscans, because it absorbed Islamic sciences had a more scientific orientation than other orders, as revealed in Umberto Eco's novel The Name of the Rose. Thus, it is evident that Christian scholasticism and concepts of medieval Christian mysticism were influenced by Muslim writers, including Imam Ghazali. Among the greatest Christian writers affected by Ghazali's thought were St. Thomas Aquinas (1225-1274 AD), he conducted a study of Arab writers and acknowledged his debt to Muslim scholars. He studied at the University of Naples (in the XIII century Frederick II founded the University of Naples) (Smith 2000: 256), where Arab literature and culture were very influential at that time. Teachings of St. Thomas Aquinas about Beatic Vision and ma'rifah (disclosure through faith) seems to take a lot from the mystical teachings of Islam, especially al-Ghazali's Sufism. The next Christian writer to be able to find the influence of Ghazali was a French mystic, Blaise Pascal (16231662 AD). His knowledge of Muslim mysticism, no doubt through his studies of Raymond Martin's work, PugioFidei in the French edition, until the end of his life when he wrote his work, the Pansees. Pascal considers that there are three methods that convey humans to strong beliefs, namely thoughts, habits, and inspiration. Only hearts are aware of God's existence and can get direct experience of God (ma'rifah), not thoughts. His belief in intuition reminded Imam Ghazali's belief in the superiority of ma'rifah to the mind. The thought of Pascal's words moved very slowly and forever failed and destroyed. However, intuition applies in flashes and is always available for action. So humans must believe it, because intuition 
is guaranteed. Intuition is gnosis that comes like lightning, but can bring a feeling of certainty (sure) (Smith 2000: 256).

According to Duncan B. MacDonald's analysis, as quoted by Amin Syukur and Masyharuddin (Zaini 2017: 157), the extent and strength of the influence of al-Ghazali Sufism in the Islamic world is due to several reasons. First, Ghazali was able to bring people (Islam) back from scholastic activities regarding their theological dogmas to the study, interpretation and appreciation of the word of God and the Sunna of the Prophet. Second, in his moral advice and teaching, he reintroduced the elements of al-khauf (fear) especially in hellfire. Third, because of the fear and influence of Sufism, it gained a strong and respectable position and was guaranteed in Islam. Fourth, he brought philosophy and philosophical theology that were originally elitist into the land of ordinary people's thinking which at first could only be understood by certain people, given that the terms and languages used were not ordinary languages, so they were a mystery. Al-Ghazali has changed or at least has tried to change difficult terms to be easy for laymen's understanding. Through a sufistic approach, Ghazalialso seeks to return Islam to fundamental and historical sources and provide a place of religious (esoteric) emotional life in its system. This was very decisive, why the teachings of the tasawuf which is an attempt to spiritualize Islam spread widely in various regions of the Islamic world until now.

But the interesting thing is that it turns out that sharing Sufism teachings that developed in the Nusantara is not easy and must always be black and white. There is the complexity of the development of Sufism in the archipelago such as the complexity of the character and diversity of the Nusantara community itself. Dividing the evolving Sufism model in the archipelago into two large patterns as if to recite other facts, where there is another axis of Sufism teachings that is more adaptive and accommodative towards both of them. There is never a meeting point between the two.

DINIKA, Volume 4, Number I, January - April 2019 
Hence, this study elaborates the spread of Ghazali'sSufism across Indonesia by three methods, i.e., from local figures, from pesantren (Islamic boarding school), and from tarekat, one of the practices of Ghazali's Sufism in Indonesia. This is to have a more comprehensive grasp on influences of Ghazali's Sufism in Indonesia.

As acquired from local figures, Ghazali's Sufism was spread by local clerics and Sufism practitioners who sided with Ghazali's principles of Sufism. One of the local clerics, Sheikh Abdus al-Shomad al-Palimbani (18th century), was the most prominent disciple and preacher of Ghazali's Sufism teachings in Indonesia. This is observable from al-Palimbani's work on Ghazali's Sufism. His works, e.g., Hidayat al-Salikinfi Suluk MaslakalMuttaqin (the translation of Ghazali's Bidayat al-Hidayah in the Malay language) (Hamid, n.d.) and Sayr al-Salikinila'Tbadat Rabb al-Alamin (Malay translation of Ibya Ulumal-Din) were highly inspired by Ghazali's writings. Further, al-Palimbani published a work entitled Fadail al-Ibyali al-Ghazali that specifically praised and elaborated the brilliance of Ghazali'sIbya Ulumal-Din (Ghazali 2013: 61-85)

Besides al-Palimbani, one of local clerics inspired by Ghazali’s writings was Kyai Ihsan bin Muhammad Dahlan (d. 1952 AD) from Jampes Kediri. He published two editions of a book entitled Sirajal-Talibin, in which it was inspired by Ghazali's final work Minhajal'Abidin. Moreover, Maraqi al-Ubudiyah by Sheikh Nawawi (1230-1314 H/1813-1897 AD) from Banten was included among works whose writings influenced by Ghazali's Bidayat al-Hidayah, as one of Ghazali'smost popular books within pesantren in Indonesia. On top of that, al-Palimbani was said to be the most prominent pupil of Ghazali's teaching whose contributions helped the spread of Ghazali's Sufism in Indonesia. This is in accordance with (Azra 1995: 271) who argues that al-Palimbani's role is an undeniable factorof popularity and acceptance of Ghazali's Sufism in Indonesia, as al-Palimbani was considered as one of the leading translators of Islamic 
books in Indonesia at the time. And the next book of Jurisprudence is Kitab Majmu'at al Sharia al-Kaifyat li al-Awamby Kyai Saleh Darat or Muhammad Saleh bin 'Umar al-Samarani (1820-1903 AD). This book contains many themes ranging from the matter of worship to muamala. The main sources of reference for this book are Ihya 'Ulum al-Din volumes I and II by al-Ghazali and others.

The clerics undoubtedly played a significant role in the spread and implementation of Ghazali's principles of Sufism in pesantren across Indonesia too. As one of the earliest Islamic education institutions, pesantren has become the vessel of nurture and spread of Ghazali's Sufism in Indonesia. This is due to the support and acceptance of Ghazali's Sufism values within the clerics and the pesantren community. As a supporting fact of the acceptance, a pesantren in Cilacap is named "Ihya" 'Ulum al-Din" after Ghazali's work. This pesantren regularly discusses and studies Ghazali's works. Ghazali's writings of Sufismare categorized into two main themes. The first theme discusses philosophical and theoretical aspects of Sufism, e.g., Misyakat al-Anwar wa Mishfat al-Asrar, and Risalah al-Laddunniyah. The second theme discusses the practicality of Sufism and emphasis on religious rituals and moral qualities (akhlaq al-karimah). The spread and discussion of Ghazali's writings in pesantren in Indonesia mainly involves the latter theme. Some of the writings are Bidayat alHidayah,Minhaj al-Abidin, and the most famous Ibya' Ulum al-Din.And Ibya' Ulum al-Din consists of three core concepts, i.e.: 1) Fi al-Tha'ah, devotion to God; 2) Fi Ijtinab al-Ma ashi, avoidance from sins and adulteries; and 3) Fi Adab al-Subbah, principles and manners of interaction between teachers and students, and among human beings.

As said by Habib Alwi bin Tahir, the Mufti of Johor, that there is no Salic that is perfect in its suluk until he reads the books of al-Ghazali (Alaydrus 2006: 86). This is taken into consideration by Imam Ghazali in his thoughts and his philosophy. But this principle does not encourage

DINIKA, Volume 4, Number I, January - April 2019 
followers to take seriously the study of philosophy. A Salic is someone who undergoes spiritual discipline in taking the path of Islamic Sufism to cleanse and purify his soul, which is also called the path of suluk. In other words, a Salic is a suluk pathfinder.The word suluk it self comes from the terminology of the Qur'an, Fasluki, in Surat An-Nahl [16] verse 69, Fasluki sub-chapter rabbikizululan, which means And take the path of your Rabb which has been facilitated (for you). Someone who takes the path of suluk is called Salic.

As well as in pesantren, studies and spread of Ghazali's Sufism take place through tareeqa teachings. Tareeqa is the association of Sufism practitioners. The walis were identified with charismatic figures commonly known as the followers of the teachings of Sufi scholars. The role of the Sufis in the spread of Islam is very evident in the role of uniting Muslims, presumably closely related to the fall of Baghdad in the hands of the Mongolians in $1258 \mathrm{AD}$ The spread of Sufi tareeqa turned out to also be in Javanese land, so many Javanese were found, Sundanese, Madurese and others who are Muslim are followers of the tareeqa.

Most of walis in Nusantara did not leave written works like other Sufi figures. The trail he left behind was seen in the collection of religious advice contained in the writing of the students in Javanese. Ghazali' works contain the record of the experience of pious people who affirm that spiritual practices (riyadhah) -as a way to train the soul and lust so that it can fight bad tendencies- are very necessary in a series of cleansing of the heart and clarifying the soul to draw closer to God, namely the closeness that leads one to the spiritual realm when the soul longs for God Divine. As anintimate relationship with God cannot be achieved by a materialistic mind, who is preoccupied with a sense of dependence on the mortal and material world, and away from religion and God.

Wali Songo remains in the path of their ancestors who are loyal to Syafi'i's mazhab in the aspects of sharia and al-Ghazali in the tareeqa 
aspect. No wonder they make the 'Ulum al-Din' a source of inspiration in carrying out their da'wa, in addition to your other Ahl Sunnah books, such as Qut al-Qulub by Abu Talib al-Makki, and Bidayat al-Hidayah and Minhaj al-'Abidin al-Ghazali. The trustees also succeeded in contributing in the form of Islamic boarding schools and madrassas which were spread throughout the country. Riyadhah and mujahadah are behaviors of spiritual life that cannot be separated from the traditions of the pesantren community. Some scholars say: "Mujahadah is not obeying the will of lust", and there is another that says; "Mujahadah is holding back lust from pleasure." Mujahadah is a means of spiritual guidance to Allah and His pleasure, while guidance is the beginning of piety (Ibrahim 2002: 17), so the mujahadah contains the element of fighting lust continuously. The definition of mujahadah in general is: struggle, earnest, hold against the enemy.

Islamic boarding schools and madrasah institutions spread throughout the country are one of the historical proofs of the contribution of the trustees ('amaljariyah). Most of the pesantren apply the teachings of Sufism al-Ghazali and teach the Ibya' 'Ulum al-Din and Minhaj al-'Abidin by al-Ghazali, as one of the basic material. The thought and practices of Sufism provide a strong impression that the Sufism pattern adopted by the saints is Sunni Sufism, which was strongly influenced by al-Ghazali's thoughts.

The development of Sufism which is quite significant has led pesantren to become the best institutions to form Muslim individuals. The influence of the values developed by Sufism provides a good provision for the santri in the pesantren. Islamic boarding schools have become a separate community, where Kyai, ustadz, santri, and boarding schools live together in an educational environment based on Islamic religious norms complete with their own norms and habits, which are exclusively different from the general public who surround them.

DINIKA, Volume 4, Number I, January - April 2019 
Moreover, Islamic boarding schools have a character that strongly teaches to educate their santri to enrich the deeds of worship, prayer, dzikr, [fasting, reading the Koran and the like, and not just sharpening the intellectual knowledge of Islamic knowledge. Because, the doctrine developed in pesantren is that knowledge is useful if it can draw closer to God. So, because the essence of Sufism is taqarrub to Allah, Sufism occupies the main position in the pesantren.

Mastering of Islamic sciences in the sense of deepening leading to figh expert is a peculiarity of pesantren in Indonesia. However, at the same time the tradition istiqoma adhered to the fiqhsufistic which was the support of the Islamic scientific tradition before the 19th century AD, which was not a deepening of science in terms of mastery to argue solely which was the purpose of pesantren, but the practice of getting closer to Allah as the main measure of one's personhood or piety. The fiqhsufistic grows and develops from the scientific tradition of boarding schools that have a very strong origin, namely Sufism and the deepening of Jurisprudence

There are two types of Tareeqawhich posit Sufism as its basic way of routine Ibadat and amaliyah, i.e., 1) Mu'tabarah, a type of tarekat considered to have compliance with the Quran and Sunnah. 2) Ghairumu'tabarah, tarekat with contrasting values against the Quran and Sunnah. On top of that, during a muktamar(meeting) of NahdlatulUlama (an Islamic cleric association) on 1984 in Situbondo, it was declared that Tareeqamu'tabarah was considered by the association to be based on Ghazali'sSufism and Junaid al-Baghdadi's thinking. The statement released by the meeting could only signify that KhuluqiAmaliSufism, or Sunni Sufism, is the only Sufism acceptable within the Nabdliyyin community, due to its compliance with the scholars' perspective.

Tareeqas are Sufi educational institutions that are specifically patterned for the purpose of cleansing the heart (tathir al-Qalb) and purification of the soul (tarkiyat al-Nafs). Someone is not enough to be 
able to understand and practice what is demanded by the Book and alSunnah without making the tareeqa as a backrest. Characters such as al-Junaid al-Baghdadi, al-Qusyairi, al-Ghazali, al-Jaylani, al-Rifầi, and al-Dasuqi, are Sufis which, agreed, contributed to inspiring the birth of the tareeqa. The Sufi order has a continuous sanad and genealogy to the Prophet Muhammad.

Sufi communities recognize Sharia as a form of servitude to Allah which starts from the stage of repentance, taqwa and ends with istiqãmah. While the tareeqa is interpreted as a continuation of the Sharia, because in the tareeqa, in addition to worshiping also has the intention to go and approach God.Tareeqa is also a term for dzikr practices based on the learning curriculum model. Congregation is also a set of tasks in the effort of self-improvement and purification of the soul as a medium to achieve the goal of "being close to God".

If we recognized the rise of learning of Sufism today, and the increasing interest of the community towards Sufism shows that since the beginning of the Islamic era in Sufism Archipelago succeeded in capturing the hearts of the wider community. These interests may be serious, may be half serious, or just want to know. But what is clear is the influence and role of Sufism, which guarantees its existence and relevance, it has not faded since now. It also by a little ignoring irregularities, which may occur, as deviations may also occur in the practice of knowledge and non-Sufism religious movements.

Thus Sufism in urban communities has been an interesting phenomenon. As Thoyibi (1996) has revealed that Sufi group memberships not only engage average Muslims, but also have included well-educated, middle class, and urban Muslims, and various Islamic social and religious organizations. However it is widely known that these religious groups cannot be disconnected from their previous religious and cultural background. As AzyumardiAzra alsosuggests, many major conventional 
and traditional groups such as Naqshabandiyyah, Rifaiyyah, Syadziliyyah, and Tijaniyyah, most of which have been associated with rural religious groups- have become dominant groups in urban areas with massive followers (Darmadi 2014: 208-209).

The presence of Sufism has a corrective meaning to the ideologization and formalization of Islam carried out by each of the Islamic modernists and jurists. The fuqaha 'mind nature emphasizes religion as a formal law and modernists develop it into a kind of ideology. Modernists and jurists approached God calculatively rationally, while Sufis approached God using the language of love and were intuitive. The religious pattern of jurists and modernists is mainly manifested in the form of obedience of servants to their masters. Such religious constructs do not give the possibility to appreciate the depth dimension of religion (Islam). Tasawuf reacts strongly to the formalization and ideologization of Islam. Sufism seeks the development of spirituality. Sufism presents God as what can be known by human knowledge. Sufis view God as the Beloved. Because of this, diversity is manifested in the form of the love of the longing for the Longed For (al-Ma'syuq). The long-term needs of Muslims are not the disclaimer of legal-formalistic figh concepts, but rather how they have a dimension of spirituality. This encounter between outward jurisprudence and inner mysticism is what is meant by fighsufistic. This convergence between Jurisprudence and Sufism is intended to help ensure that figh is not trapped in logo centrism, formalism, and symbolism which continues to sag to lose its spirit and spirit. Moeslim Abdurrahman has suggest that Sufism among different classes may manifest diversified patterns of Sufism, both the religious and cultural expression (Darmadi 2014: 209).

Although there are indirectly classical and conventional roots, they actually learn deeply about each teaching and practice it in everyday life. The desire of the urban community to return to life at the root of religious culture that is religiously religious. Not just an actual formality but also 
has a deep meaning for everyday life. But if we look further, we should continue to be evaluated because Sufism is in contact with industries that tend to be double-edged. Apart from the pluses and minuses of teaching, also the patterns and portraits of his life which almost led to the pseudo mysticism, his enthusiasm and influence brought an important meaning to Islam in the midst of society. Moreover, the city community who really missed the treasures of religious life.

\section{Conclusion}

Allegations of Sufi teachings are the main cause of the weakness of the social, economic and political ethos so that the majority of Muslims are classified as poor and have low education due to misunderstandings that define Sufi teachings, which clearly come from Al-Qurán and al-Sunnah.

Sufi teachings can be the ethical basis of the dynamics of social, economic and political life that are humanistic and just in the global world, if interpreted as humanitarian praxis. The root of Sufi ethics is the willingness of humans to place material and worldly dynamics (social, economic, political) as a vehicle for achieving higher levels of life (maqam). For Sufis, social, economic and political life is not the final goal, but the ladder for life is higher. This is the meaning of suluk teachings as a way to reach ma'rifah.Ma'rifah is the highest gift about the nature of the dynamic life of nature and humans. The futuristic ma'rifah gift creates human beings who are good at seeing the causal laws of history and various possible events in the future.

Therefore Ghazali'stasawuf can be considered to have merged deeply in the Nusantara society, especially in Indonesia in the form of FiqhSufistic.It can be seen from the Ghazali' books that greatly influenced the tradition of learning Islam in Indonesia, especially the book of IhyaUlum al-Din. It could still be seen in three aspects. Firstly, Muslim Clerics; secondly, Pesantren; and thirdly, tareeqa.

DINIKA, Volume 4, Number I, January - April 2019 


\section{References}

Abduh, M. Arrafie, and Syofrianisda. 2018. "Corak dan Pengaruh Tasawuf al-Ghazali dalam Islam.” Usbuluddin 25 (1). https://doi.org/ http://dx.doi.org/10.24014/jush.v25i1.2559.

Al-Subuki, Taj al-Din. 1992. Thabaqat al-Syafi iyah al-Kubra. 6th ed. Giza.

Al-Taftazani, Abu al-Wafa al-Ghanimi. 1979. Madkhalila al-Tashawnuf al Islami. Kairo: Dar al-Tsaqafah li al-Nasyrwa al-Tauzi`.

Al-Wafa, Al-Ghanimi al-Taftazani abu. 1979. Madkhalila al-Tashawnuf al Islami. Cairo: Dar al-Tsaqafah li al-Nasyrwa al-Tauzi'.

Alaydrus, Novel Muhammad. 2006. Jalan Nan Lurus: Sekilas Pandang Tarekat Bani 'Alawi. Surakarta: Taman Ilmu.

Azra, Azyumardi. 1995. Jaringan Ulama: Timur Tengah dan Kepulauan Nusantara Abad XVII dan XVIII. Bandung: Mizan.

Darmadi, Dadi. 2014. "Urban Sufism: The New Fluorishing Vivacity of Contemporary Indonesian Islam.” Studia Islamika 8 (1). https:// doi.org/https://doi.org/10.15408/sdi.v8i1.700.

Ghazali, Abd. Muqsith. 2013. "Corak Tasawuf Ghazaali dan Relevansinya dalam Konteks Sekarang." Al-Tahrir 13 (1).

Hamid, Al-Ghazali Abu. n.d. Al-Munqid₹, Min al-Dhalalal. Beirut, Libanon: Maktabah Dar al-Tsaqafiyah.

—. n.d. Bidayat al-Hidayah. Beirut, Libanon: Dar al-Fikr.

—. n.d. Fadha'ikh Al-Bathiniyyah. Kuwait: Mu'assasah Dar al-Kutub al-Tsaqafiyah.

- n.d. Ibya' 'Ulum al-Din. Beirut: Dar al-Fikr.

- n.d. Maqashid al-Falasifah Fi al Manthiqwa al-Hikmah al-Ilabiyyahwa al-Hikmah al-Thabi iyyah. Egypt.

—. n.d. Tahafut al-Falasifah. Edited by Sulaiman Dunya. Egypt: Dar al-Ma'arif.

Huda, Shokhi. 2008. Tasawnf Kultural: Fenomena Shalawat Wahidiyah. Yogyakarta: LKiS.

Ibrahim, Majdi Muhammad. 2002. Al- Tashawwuf al-Sunni: Hal al-Fana' Bayna al-Junaidwa al-Ghazali. Maktabah al-Tsaqafah al-Diniyah.

Ismail, Ilyas. 2013. True Islam: Moral, Intelektual, Spiritual. Jakarta: Mitra Wacana Media. 
Madjid, Nurcholis. 1984. Khazanah Intelektual Islam. Jakarta: Bulan Bintang. Masrur, Ali. 2017. "Pemikiran Tasawuf Ortodoks di Asia Tenggara: Telaah Atas Kontribusi al-Raniri, al-Singkili, dan al-Makasari." Syifa AlQulub 1 (2): 152-59. https://doi.org/https://doi.org/10.15575/ saq.v1i2.1431.

Qardhawi, Yusuf. n.d. Al-Ghazali Bayna Madibi Wa Naqidzibi. Beirut, Libanon: Mu'assasah al-Risalah.

Rahman, Fazlur. 2000. Islam. Bandung: Penerbit Pustaka.

Satuni, Arafat Karam. 2013. Huijat al-Islam al-Ghazali Wa Athwarubu alFikriyah.

Sholihin, Muhammad. 2005. Melacak Pemikiran Tasawnf di Nusantara. Jakarta: Raja Grafindo Persada.

Smith, Margareth. 2000. "Al-Ghazali: The Mystic." In Pemikirandan Doktrin Mistis Imam al-Ghazali, edited by Amrourani. Jakarta: Riora Cipta.

Suteja. 2018. Tasawnf di Nusantara: Tadarus Tasawuf dan Tarekat. Cirebon, Jawa Barat: Aksara Satu.

Yunus, Mahmud. 1982. Sejarah Pendidikan Islam di Indonesia. Jakarta: Bhatara.

Zaini, Ahmad. 2017. "Pemikiran Tasawuf Imam al-Ghazali." Esoterik: Jurnal Akblak dan Tasawuf 2 (1). https://doi.org/http://dx.doi. org/10.21043/esoterik.v2i1.1902.

DINIKA, Volume 4, Number I, January - April 2019 